\title{
Sôbre a Poesia Romântica no Brasil
}

Toriciando o aparecimento em 1813 do primeiro jornal brasileiro 1 que em suas páginas abria lugar para a literatura, afirmava Hipólito da Costa: "Há dez anos, estando a Côrte em Lisboa, que ninguém se atrevia a dar a um jornal o nome de Patriota; e a Henriáda de Voltaire entrava no número dos livros que se não podiam ler sem risco de passar por ateu, pelo menos por ser Jacobino. $\mathrm{E}$ temos agora que em tão curto espaço já se assenta que o povo do Brasil pode ler a Henriada de Voltaire; e pode ter um jornal com o título de $O$ Patriota, termo que estava proscrito como um dos que tinham cunho revolucionário; ... nós julgamos isto matéria de importância; porque é seguro indício de que o terror inspirado pela Revolução Francêsa, que fazia desatender a tôda a proposição de reformas, principa a abater-se, e já se não olha para as idéias de melhoramentos das instituições públicas, como tendentes à anarquia, em vez de servirem à firmeza do Govêrno."

Esse terror às reformas inspirado pela Revolução Francesa intensificara-se com a Inconfidência Mineira, tão ligada àquela no campo das idéais liberais. Esta revolução abortada de Minas Gerais, em que se viram envolvidos os "árcades" (vale dizer: os únicos grandes poetas da colônia, com exceção do seiscentista Gregório de Matos), teve duas consequências bem funestas para a cultura e a poesia brasileiras: desterrou para a África os árcades (e com êles, naturalmente, a poesia do Brasil) e, acentuando a repressão às idéais relativas ao liberalismo, aos "direitos do homem", aos estudos filosóficos, aumentou a vigilância que fizera depender, havia muito, a impressão e a circulação de livros da censura régia.

Assim coibidos, os poetas tentam conservar o arcadismo protoromântico dos desaparecidos mineiros, para o que thes falta sufi- 
ciente valor, ou refugiam-se em fracos poemas religiosos, na maioria inspirados ou parafraseados da Bíblia, em odes empoladas e em poesias que assinalam uma volta ao classicismo, isso quando o classicismo estava moribundo. Em suma: poetas havia, o que não havia era poesia.

E por muito tempo foi assim. Em 1808, o regente D. João, fugindo dos exércitos de Napoleão, realiza a inaudita façanha da transferência da sua côrte de Lisboa para o Rio, abre os portos da colônia ao comércio internacional, funda a primeira das nossas tipografias regulares, publica o primeiro jornal brasileiro, atende ao desenvolvimento do ensino, da indústria, das belas-artes, cuida da abertura da Biblioteca Nacional; o país progride tanto que em menos de dez anos é elevado à categoria de Reino Unido ao de Portugal. Tudo se transforma nessa era febril, mas a poesia continua vegetando nas mãos dos pseudo-clásicos, poetas sem nenhuma inspiração, como o provam as obras poéticas saídas dos prelos da Impressão Régia e as que se publicaram naquele mesmo jornal de que fala Hipólito da Costa.

Mal retornara D. João VI a Portugal quando D. Pedro, regente do reino, proclamou a Independência, a que se seguiram os anos tormentosos do primeiro império, a abdicação em favor do menino D. Pedro II e o tempo ainda mais tormentoso da Regência. As transformações que sofreu o Brasil atingiram então um ritmo vertiginoso; êsses foram os anos do fortalecimento da consciência nacional e, em suas reformas, suas batalhas parlamentares, suas revoluções e seus jornais de combate, a violência, o patriotismo e a oratória bem pouca margem deixaram à literatura. A poesia, pois, continuou na mesma situação de mediocridade; e nem sequer a introdução do romantismo em 1836 a afastou seriamente daí.

Neste ano, no primeiro número da Niterói, efêmera "revista brasilense de ciências, politica e artes" editada em Paris por um grupo de brasileiros, publicou Magalhães, um dos editores, um "Ensaio sôbre a História da Literatura Brasileira", espécie de manifesto romântico. E, ainda de Paris, nesse mesmo ano, exportou para o Brasil os medíocres frutos dos seus esforços em prol da nova corrente. Os laboriosos Suspiros Poéticos e Saudades repousam hoje na justa paz do esquecimento; mas ao tempo em que foram publicados, apesar das suas poesias estarem mais longe da sensibilidade 
romântica que muitas páginas dos árcades mineiros, obtiveram sucesso e valeram a Magalhães, pelo que representavam de novidade intencional, o título de introdutor do romantismo no Brasil.

Magalhães, porém, era um medíocre poeta, a quem o romantismo só interessou superficialmente (no fundo, nunca deixou de ser o pseudo-clássico das suas primeiras Poesias, como o prova a regressão completa a essa maneira de ser que ap̉resentam as suas produções posteriores aos Suspiros Poéticos), e não seria êle quem salvaria a poesia nacional da triste situação em que se encontrava. Por outro lado a mundança brusca do nosso meridiano literário de Coimbra para Paris —estimulada talvez por aquela mesma aversão patriótica que, nesse período da consolidação da Independência, levou honestos a pacatos cidadãos à adoção de nomes indígenas, quer no nome civil quer em títulos nobiliárquicos; exemplo: Domingos José de Magalhães, Visconde de Araguaia-, cortando a ligação da literatura brasileira à portuguêsa, que sempre, em primeira ou segunda mão, fornecera os nossos modêlos poéticos, e não oferencendo, ademais, uma nova e exemplar linguagem poética, deixou os vates da época sem saber o que fazer, a quem seguir.

A solução dêsse problema caberia, dez anos mais tarde, a Gonçalves Dias. Então iam já serenanido os ódios provocados por aquelas lutas políticas, e o poeta maranhense, ao acabar seus estudos na velha Coimbra, onde o romantismo estava em ebulição, pôde trazer para a pátria a extraordinária linguagem poética dos seus Primeiros Cantos, realmente romântica na sensibilidade e na inspiração. Ademais, segtindo a tendência geral do romantismo de servir-se de assuntos medievais (em substituição aos greco-romanos do classicismo) para a criação poética, êsse mestiço de índio não só se serviu do melhor que a sua ancestralidade européia lhe forneceu como criou o "indianismo".

$\mathrm{O}$ índio na obra de Gonçalves Dias é um índio diferente, em temperamento e ações, dos índios dos épicos mineiros do século XVIII; é, naturalmente, ưm índio romântico, tão romanticamente idealizado como os cavaleiros de Sir Walter Scott. Mas foram os portuguêses, sob cuja sombra se formara o poeta, os primeiros a reconhecer a validade dessas "poesias americanas" dos Primeiros Cantos; exatamente lamentando o pouco espaço que aquelas ocupavam nestes, declarou Herculano -que com Garrett, o mestre de Gonçalves 
Dias, forma o par mais importante na literatura romantica de Portugal-: "Esse Novo Mundo que deu tanta poesia a Saint-Pierre e a Chateaubriand é assás não rico para inspirar e nutrir poetas que crescerem à sombra das suas selvas primitivas." Era mais que o reconhecimento, era o aplauso ao indianismo.

E Gonçalves Dias, aperfeiçoando os seus conhecimentos de antropologia e linguística indígenas, estudando com mais afinco os costumes dos índios nos velhos cronistas coloniais, pôde assim deixar, esparsos entre a sua grande obra lírica, alguns poemas indianistas do mais alto valor (leiam-se, como exemplos, essa obra-prima de concepção e andamento que é "I-Juca-Pirama" e "Leito de Fôlhas Verdes", uma jóia lírica).

O "caso" do indianismo na literatura brasileira tem sido muito discutido e a complexidade dos ataques e defesas não permite sequer, num artigo ligeiro como êste, uma sumarização decente. Registre-se, no entretanto, que não se discutem tanto os costumes e os têrmos indígenas utilizados por Gonçalves Dias (e Alencar, no romance), costumes e palavras de fácil justificação, aliás, nos cronistas quinhentistas; o centro da questão tem sido a "falsidade" dos sentimentos e da maneira de pensar e se exprimir das personagens indianistas.

Para não entrar em longos debates, convém observar apenas que a crítica não tem querido usar do argumento primário de que ao poeta assistia o direito de idealizar as suas personagens de acôrdo os conhecimentos e as idéias que possuia sôbre o índio, conhecimentos e idéias que eram também os da época romântica. Em outras palavras, o direito de romantizar o índio como criação poética.

O indianismo, além do mais, não foi senão um dos aspectos da obra de Gonçalves Dias, obra extraordinária pelo que tem de bela, de correta, de contida, de sincera e de viril no tratamento poético da natureza e do amor (v. "Se se morre de amor", "Ainda uma vez iAdeus!", "Olhos Verdes" e a mais conhecida, e uma das mais perfeitas também, das poesias brasileiras - a "Canção do Exílio").

Nessa obra a poesia nacional encontrou o caminho perdido e o romantismo, o seu grande mestre.

A geração seguinte, com efeito, serviu-se abundantemente de seus assuntos, ritmos, imagens e até do seu vocabulário. Infelizmente não the seguiu de perto o exemplo de usar a língua como ins- 
trumento artístico. Os rapazes da segunda geração romântica, à exceção talvez de Alvarez de Azevedo, não tiveram nunca grandes preocupações de ordem estética; sofreram do "mal" da espontaneidade artística, ignoraram quase o que há de "arte" (no sentido de artesanato) em tôda arte. Daí a frouxidão que tantas vezes lhes prejudica os versos, daí, parcialmente, a desorganização de tantos dos seus poemas.

Não me refiro aquí, nesta questão de trabalho artístico, tão sòmente aos problemas comuns do português do Brasil (neste ponto a segunda geração, sem que importe a causa, "abrasileirou" mais a língua; até abrandou uma certa dureza comum em versos de Gonçalves Dias) mas também aos de estética da língua; essa ignorância, ou despreocupação, aliađa à falta de cultura geral (ou originária dela, não importa para o caso), às inovações e à sensibilidade do momento, possivelmente explicará a facilidade característica da poesia dessa geração, por isso mesmo tão perto do povo, tão amada por êle.

. Nem mesmo o excepcional Álvarez de Azevedo -o culto, o cético, o satânico, o mordaz Álvarez de Azevedo, o mais aristocrático temperamento da poesia romântica- conseguiu escapar a essa popularidade quando se entregou ao sentimentalismo fácil de "Se eu morresse amanhã" (ou ao satanismo não menos fácil dos contos d A Noite na Taberna).

Esse quase-menino Álvarez de Azevedo, cuja obra desigual só resistiu em parte, "foi poeta, sonhou e amou na vida", conforme reza o seu auto-epitáfio; e foi sobretudo um achado para a poesia brasileira. Recebeu a herança de Gonçalves Dias e, com o seu profundo conhecimento da poesia européia sua contemporânea, abriu novos horizontes ao romantismo brasileiro. Misturou sentimentalismo, nostalgia, "morrer de amor" com "amor e mêdo", pessimismo, ceticismo, satanismo e humour na Lira dos 20 Anos. Nessa lira, tão influenciada por Byron e Musset, se o número de poesias de primeira ordem é bem pequeno, há em compensação muitas passagens extraordinárias; e há sobretudo as novas cordas que tanto enriqueceram a lírica romântica,

Uma delas, a que Mario de Andrade batisou de "amor e mêdo", permite considerações que muito contribuem para a compreensão do lirismo amoroso da época. O "amor e mêdo", out seja: o 
mêdo da realização do amor, foi, com exceção do caso de Álvares de Azevedo -explica o grande mestre paulista-, "mais assunto poético que realmente sentido"; Manuel Bandeira relacionou esta explicação a uma outra de Gilberto Freyre para o culto diferenciador da mulher na sociedade brasileira, o qual "bem apurado, é, talvez, um culto narcisista do homem patriarcal, do sexo dominador, que se serve do oprimido - dos pés, das mãos, das tranças, do pescoço, das coxas, dos seios, das ancas da mulher como de alguma coisa de quente e de doce que the amacie, the excite e the aumente a voluptuosidade e o gôzo. O homem patriarcal se roça pela mulher macia, frágil, fingindo adorá-la, mas na verdade para sentir-se mais sexo forte, mais sexo nobre, mais sexo dominador".

Esta luminosa suposição de Freyre deixa entrever bem o que há de fingimento, de "pôse", no "mêdo" dos românticos ao amor, na adoração à mulher (à mulher em si ou nos seus atributos mais marcadamente feminos: seios, mãos, etc.) e sobretudo, acredito, na autocomiseração, na lamentação do poeta em face da vida e do amor.

É, entretanto, necessário, não se perder de vista o fato de que a volta à idade média (não necessariamente em assunto, mas em idéais de certa categoria) teria tido a sua influência na expressão poética dêsse culto à mulher. Aliás idade média e patriarcalismo rural brasileiro não estavam a êsse respeito tão distantes quanto se poderá pensar.

A auto-comiseração poética (atitude na qual é necessario ver-se também a influência do "mal du siècle") estaria naturalmente ligada a poesia de "amor e morte", também bastante posada nos poetas da segunda geração romântica, com exceção, a meu ver de Junqueira Freire. Neste a oscilação entre o desejo de amor e o de morte décorre das condições da sua própria vida: queria o amor com ânsia (era um temperamento sensual), mas na impossibilidade do amor (foi frade, sem vocação, aliás), voltava-se para o desejo da morte nas suas "horas de delírio". Essa luta interna enriqueceu-lhe as Inspirações do Claustro de uma forma extraordinária; nelas perpassa o amor, perpassam o mêdo e todos os sentimentos que a geração exprimiu, mas perpassam também o ódio, o desespêro e a piedade. Em notas; aliás, que explicam a valorização recente da poesia dêsse "posseso" que tantas vezes parece um poeta de hoje (compreender-se-á que a sua poesia não podia, por razõos de ordem 
social, religiosa e moral, tertido aceitação ao tempo em que foi publicada).

Mais artista que Freire, porém menos interessante, foi Varela, cuja longa obra (viveu mais que os outros) ocupa um lugar na passagem entre a segunda geração romântica e a terceira, isto é, Castro Alves (os outros não resistiram ao tempo). Varela tem menos "facilidade" que aquêles e ainda não alcança o "vôo" don condor Castro Alves; por outro lado, pouco sofreu do ceticismo de geração precedente, em realidade voltou à crença confessada de Gonçalves Días. E, como êste, sobressai como cantor da naturezạ.

Desiludido đo amor, maltratado pelo destino, Varela não se apega ao ceticismo mas ao álcool, à vagabunđagem pelas estradas e matas do interior, ao amor de Deus através do amor à criação. Daí a sua capacidade de "sentir" a natureza muito mais que o comum dos mortais, a subjetivação da natureza no poeta e a "sugestão" dela nas suas poesias. Segundo observou Mário de Andrade, a gente em Castro Alves pode visualizar a floresta, tal a precisão de detalhes oferecida, mas em Varela a gente "sente" a floresta. Pena que essas passagens, capazes de nos fazer sentir a-natureza tão subjetivamente, se percam entre versos e versos banais, sem interêsse de espécie alguma. Esse defeito, essa irregularidade qualitativa dos versos $\mathrm{e}$, também, o alongamento sem necessidade da composição aparecem até nas melliores poesias de Varela (v. "Cântico do Calvário" e "Juvenilia"), tornando-o bem inferior como poeta.

Castro Alves, que ten êsses mesmos defeitos, compensa-os com a sua genialidade. Há nele, frequentemente, mau gôsto, falta de concisão, oratória desproporcional, - mas a gente perdoa pela grandeza humana da sua poesia, pela sua exuberância de extrovertido embriagado com a própria glória. Castro Alves foi, com efeito, o cantor de "amor e glória"; quer nos seus poemas de amor," quer na sua obra social em defesa d Os Escravos, o que o poeta visava era a glória, a glória materialada nos aplausos públicos. Daí a sua eloquência transbordante.

Visando ser compreendido pelo seu público, visando diretamente o aplauso em grande estilo que só o transporte, o entusiasmo frenético, poderia arrancar dêsse público de teatros e meetings, Castro Alves teve necessariamente de adaptar a sua lira ao seu público. As qualidades de subjetivação, que caracterizam os outros 
poetas românticos, dão lugar a fatos objetivos, a descrições capazes de fazer o público "ver"; a musicalidade do verso (é ainda Mário de Andrade quem observa) se transforma em sonoridade, de maior efeito sôbre a massa; a palavra ganha volume, o assunto se transforma em motivo. Enfim, a poesia, se não despreza comover, passa a tratar, em primeiro lugar, de "convencer". Para maior glória do poeta,

Mas, apesar da consecução de sua finalidade, e apesar das obras primas que legou (v. "O Navio Negreiro", "Vozes d'África") ao lado de muitas poesias de grande valor lírico (v. "Boa Noute", ns "tiranas" d Os Escravos como exemplos), a poesia de Castro Alves representou um nefasto passo na evolução do gênero no Brasil. Isso porque desprendeu a poesia romântica do lirismo subjetivo no que pôde, submeteu-a à influência da oratória melodramática e, passando adiante sem citar outras razóes, porque abriu caminho para a adoção do parnasianismo francês, poesia de motivos, de objetivismo, visualista, pictórico ou escultural, de formas perfeitamente definidas, poesia que dominaria por completo as novas geraçôes, e que foi um êrro na nossa história poética. Para facilitar a compreensão do que foi a praga do parnasianismo no Brasil nada melhor que a anedota da composição do "soneto": o poeta o começa pelo último verso, a "chave de ouro", depois, com o dicionário de rimas à mão, escreve a última palavra de cada verso, lança no alto da página um título relacionado com a chave de ouro, e, finalmente, enche o esqueleto métrico com versos sôbre o tema oferecido pelo título.

O parnasianismo foi a morte do romantismo. E, mais que isso, foi uma ditadura, a ditadura da mediocridade poética, que durou trinta anos e que réquereu uma revolução literária para desaparecer. E só quando a exaltação revolucionária dos modernistas se atenưou, por volta de 1930, foi que a poesia se sentiu livre. Em muitos casos para afirmar um neo-romantismo.

Mario Camarinha-Da-Silva, University of California, Berkeley. 